\section{BREEDING OF RUDDY SHELDUCK (TADORNA FERRUGINEA) AT SAYAJI BAUG ZOO, VADODARA, GUJARAT}

\section{Raju Vyas}

Sayaji Baug Zoo, Vadodara, Gujarat 390018, India Email: razoovyas@hotmail.com

The Ruddy Shelduck (Tadorna ferruginea) is one of the resident-migrant birds, which is also known as Brahminy Duck in India. The species is very widely distributed in the subcontinent. It breeds in south of Spain, North Africa, Nile delta, south-eastern Europe, Asia Minor, Mesopotamia, Persia, Central Asia to east Mongolia and southern China. It visits Sudan, Abyssinia, and the whole of India, Manchuria (northeastern China), Korea and rarely Sri Lanka in winter. It is a rare vagrant in the rest of Europe, occasional to Iceland and North America and Japan and a scarce winter visitor to Myanmar and Indo-China (Delacour, 1954; Ali \& Ripley, 1983).

The Ruddy Shelduck is a strong and successful species, which occupies a very large range and can accommodate itself to various conditions. Reports show that many subpopulations have been reduced in numbers due to the anthropogenic activity especially due to excessive habitat destruction, alteration of habitat and illegal hunting of Sheldgeese \& Shelducks. This species is considered sacred in Ladakh, Nepal, Tibet and in Mongolia and these countries are the breeding ground of the species. Therefore, the Asian population of Ruddy Shelduck is in a good numbers but it has its reverse in North Africa and Europe, where the status of the species is in jeopardy. But established reserves have possibly partially negated some reverses.

Ruddy Shelducks are denizens of interior fresh water, only occasionally seen on the seashore. They live in pairs, congregating after the breeding season. Male and female colour buff and orange-chestnut; female comparatively smaller and little darker than the male, the face is whiter; the wing-coverts are more often pure white, and lacks black collar (Ali \& Ripley, 1983).

Usually the species nests in burrows in sand or clay-bank holes, or tree hollows up to $30 \mathrm{ft}$ above the ground, rock or cliff crevices and buildings. Old raptor nests are also utilized as nest sites (Delacour, 1954).

Their bright plumage, handsome appearance, their great tameness and their extreme wariness, make them as useful as 'watch dogs' and on that account the species is very popular in captivity. History of zoo-captivity shows that the species has been kept since long before Egyptian and Greek civilizations. The London Zoo for the first time kept the species in 1850 and bred successfully in 1859 (Delacour, 1954).
Shelducks were kept in separate cages. The cage size was 6.4 x 4.8 and $2.4 \mathrm{~m}$ high, covered with weld-mesh, with a water pool in middle and top half of roof covered with mesh for sufficient sunlight. The water pool was irregular in shape, $22 \mathrm{~m}^{2}$ in area with $0.5 \mathrm{~m}$ deep; water in the pool was changed every week. The cage was decorated with large dry logs and branches and an earthen pot was provided as a nesting burrow in the back corner of the cage. The birds were fed on mixed grains and green chopped coriander leaves ad libitum. About $100 \mathrm{~g}$ chopped meat or fish was also provided. Both the birds had settled well in the cage and exhibited normal routine activity.

During 1997 winter, when molting was completed the birds acquired breeding plumages before summer. Both the birds called simultaneously. The female flew from the water surface to the perching branch and again into the earthen pot and the male followed her. During the month of March, it was observed that when the female entered the pot, the male stood guard by it. The birds were very aggressive and displayed their displeasure with stress calls and by attacking the keeper when he entered the cage for routine work.

The female laid the first egg in the last week of March 1997. The male bird always guarded the nest by staying outside the pot or on top when the female was inside the pot. She laid a total of six creamy-white eggs. The clutch size was smaller than the published report of 8-16 eggs (Delacour, 1954). Average egg size was $6.44 \times 4.6 \mathrm{~cm}$ and weight was $65-70 \mathrm{~g}$. The female started incubation very seriously from 7 April 1997. On 6 May 1997, two eggs hatched after 30 days of incubation. The ducklings were white in colour with black and dark grey spots on their body. Three infertile eggs and one egg in its early stage of embryo development were found. Also it was observed that most of the time the female incubated the eggs and the male guarded the nest. The male took on a few minutes of incubation duty when the female came out to forage.

Both ducklings were white with grey back, shoulder and head. One duckling died after two weeks on 21 May 1997. The surviving duckling developed fast and by the end of June 1997, it almost looked like an adult bird.

The present breeding record shows that if special care and nesting atmosphere are provided to the bird species, it can breed very well in captivity.

I am very thankful to late V.A. Jadeja, Curator, Sayaji Baug Zoo, Vadodara for his support during the study.

\section{REFERENCES}

Ali, S. and S.D. Ripley (1983). Handbook of Birds of India and Pakistan (Compact Edition). Oxford University Press, New Delhi, $737 \mathrm{pp}$.

Delacour, J. (1954). The Waterfowl of the World, Vol. I. London, 284pp. 